\title{
Agroforestry practices in Tamil Nadu, India - a boon for farmers for livelihood security
}

\author{
S. Saravanan ${ }^{1, *}$ and Nanita Berry ${ }^{2}$ \\ ${ }^{1}$ Silviculture, Forest Management and Agroforestry Division, Institute of Forest Genetics and Tree Breeding (ICFRE), Forest Campus, \\ R.S. Puram, Coimbatore 641 002, India \\ ${ }^{2}$ Silviculture, Forest Management and Agroforestry Division, Tropical Forest Research Institute, RFRC (PO), Mandla Road, \\ Jabalpur 482 021, India
}

Agroforestry systems establish a symbiosis among agriculture crops, tree species and raising livestock on the same unit of land. In other words, these are complementary and beneficial to each other. Agroforestry is the system of developing agricultural land in combination with forestry technologies. Agroforestry practices in Tamil Nadu (TN), India, have existed since time immemorial and are evidenced in all parts of the state with less or no scientific management. Agroforestry research is a new field that is getting momentum in recent times due to popularization of industrial agroforestry. In the present context, to meet the national target of forest cover $(33 \%)$ and to reduce pressure on natural forests, agroforestry plays a vital role and provides additional income to the farming community. This article aims to provide an insight into agroforestry practices in $\mathrm{TN}$, including reasons for opting them, problems faced, etc. It also provides information on agroclimatic zone-wise tree species and agroforestry systems being practised by farmers, central and state government initiatives towards promotion of agroforestry, new technological interventions, etc. for the welfare of the farming community.

Keywords: Agricultural land, agroforestry systems, farming community, economic upliftment, technological interventions.

AGROFORESTRY is a land-use management system in which trees or shrubs are grown around or among crops or pastureland. This intentional combination of agriculture and forestry has varied benefits, including increased biodiversity and reduced erosion ${ }^{1}$. The benefits of agroforestry are reduced poverty through increased production of wood and other products, increased food security by restoring soil fertility for food crops, multifunctional site use, reduced global warming and hunger risk by increasing the number of drought-resistant trees and the subsequent production of fruits, nuts and edible oils, reduced deforestation and pressure on woodlands by providing farm-grown fuelwood, reduced need for toxic chemicals, improved human nutrition through more diverse farm

*For correspondence. (e-mail: saravanans@icfre.org) outputs, growing space for medicinal plants, etc. ${ }^{2}$. Agroforestry is being practised in Tamil Nadu (TN), India, in all the districts falling in seven agroclimatic zones and these are in the form of traditional adoption since time immemorial to recent industrial agroforestry. The expansion of industrial agroforestry models is rapid in almost all the regions of $\mathrm{TN}$ along with traditional models. Traditionally valuable trees like teak (Tectona grandis), bamboo species, silk cotton (Ceiba pentandra), tamarind (Tamarindus indica), khamair (Gmelina arborea), Casuarina species, Eucalyptus species, Malabar neem (Melia dubia), Maha neem (Ailanthus excelsa), kadamba (Neolamarkia cadamba) and fruit trees, like mango, guava, lemon, sapota, papaya, amla, etc. Farmers commonly grow annual crops like cowpea, black gram, green gram, gingelly, turmeric, cotton and groundnut with teak, Eucalyptus, Casuarina and Gmelina due to its easy marketing and high economic returns under traditional and industrial agroforestry systems ${ }^{3}$.

TN presently has $20.27 \%$ of forest and tree cover ${ }^{4}$. However, for attaining 33\% forest cover according to the National Forest Policy (NFP) 1988, it is essential to promote trees outside forests (TOF) through agroforestry under various schemes like farm forestry and social forestry by establishment of industrial agroforestry. The total population of $\mathrm{TN}$ is 7.21 crores, of which $51.6 \%$ is rural, including $1.12 \%$ tribal population ${ }^{5}$ whose potential can be effectively utilized in the promotion of tree farming as a major economic activity to meet the domestic and industrial demands sustainably. Likewise, significant livestock population of the state can be properly managed through adoption of different silvopastoral (fodder trees and forage crops; Acacia leucophloea with Cenchrus ciliaris naturally evolved silvipasture system in the districts of Coimbatore and Erode over 1.20 lakh ha) and hortipastoral systems. With the increasing gap in demand and supply of forest produce in India from natural forests, the role of agroforestry seems to be significant in filling the gap. As far as agriculture in TN is concerned, it occupies a unique position with seven agroclimatic regions that grow all kinds of crops like rice, jowar, ragi, bajra, maize and a variety of cereals, pulses, oilseeds, fruits and vegetables. The state also occupies a special place for 
agricultural produce in the country. The farming sector in $\mathrm{TN}$ forms the mainstay of its economy and the primary source of employment for over $52.45 \%$ of its population. It contributes almost $23 \%$ of the gross state domestic product (GSDP) and about $45-50 \%$ of the rural income. In 2018-19, the agricultural sector contributed around $24 \%$ of $\mathrm{GSDP}^{6}$.

\section{Central and state government initiatives in the promotion of agroforestry in Tamil Nadu}

TN is gifted with rich natural resources, good climatic conditions (temperature and rainfall), and liberalized industrial policies, which makes it favourable to set-up agro-based and wood-based industries to process the raw material produced from agroforestry systems. Agroforestry initiatives had started during the 1990s itself in TN, to meet the demands of wood-based industries after the recommendations of the NFP, 1988 (ref. 8), which directed wood-based industries to generate their raw resources rather than depend on the Forest Department for their requirements ${ }^{8}$. The government of India launched the National Agroforestry Policy (NAP), 2014 to identify bottlenecks in the expansion of agroforestry in the country and pathways to remove the constraints systematically ${ }^{9}$. The main objectives of NAP are to encourage and expand tree plantation in complementary and integrated manner to improve productivity, employment, income and livelihood of rural households, especially the small-holder farmers. This will help to protect and stabilize ecosystems and promote resilient cropping and farming systems, meet the raw material requirements of woodbased industries, supplement the availability of agroforestry products (AFPs), such as the fuel wood, fodder, nontimber forest produce and small timber of the rural and tribal populations. Increasing the tree cover in agroforestry systems will reduce the pressure on existing natural forests. There is a need to develop capacity and strengthen research in agroforestry and create a massive people's movement for achieving these objectives. The Central Government has directed all the states to change the forest produce, timber felling and transit rules for farm-grown trees to ease the tree felling operation and minimize the pressure on natural forest. Further, recently, bamboo has been de-notified by the central government as timber under the Indian Forest Act (1927), exempting it from timber-felling and transit rules when grown outside the forest areas, to easily harvest it without legal hurdles to meet the requirement. The National Bamboo Mission (NBM) and State Bamboo Mission of the concerned states support the cultivation of bamboo species in farmlands by providing financial support to farmers. Greening programmes like farm forestry and social forestry are found to be effective in many districts in $\mathrm{TN}$, which were initiated in the early 1970s. In the 1990s the
TN government initiated the "Tamil Nadu Afforestation Programme' ${ }^{10}$ and 'Tree Cultivation in Private Lands"11 and 'Tamil Nadu Biodiversity Conservation and Greening Project ${ }^{12}$ supported by JICA (Japan International Cooperation Agency), to create awareness among farmers on tree farming for higher economic returns. Similarly, the involvement of wood-based industries for agroforestry is found beneficial for procurement of raw materials from agroforestry. Wood-based industries are also promoting industrial agroforestry with farmers through contract farming with minimum support price for tree species like Eucalyptus, Casuarina, Melia dubia, Ailanthus excelsa, Neolamarkia cadamba, etc. The wood-based industries also provide quality planting material (mostly clones), precision silvicultural techniques, harvest and postharvest technologies for higher net farm income in short rotation period of 3-6 years. The government has issued a special order to promote sandal cultivation in farm lands with $80 \%$ return to medium and large farmers. To promote agroforestry in $\mathrm{TN}$, the government relaxed the timber transit rules and admitted free transport of 37 different tree species within the state. Research institutions (Indian Council of Forestry Research and Education (ICFRE), Tamil Nadu Agricultural University (TNAU) and Tamil Nadu Forest Department (SFD)) and woodbased industries are also involved in developing highyielding clones for more productivity and higher income to farmers in short rotation period. In the present scenario, agroforestry is promoted by providing quality planting materials (mostly clones), which are site-specific for obtaining more yield, and farmers are provided institutional support with tree insurance. The wood-based industries purchase the pulpwood at a pre-decided support price or the market price, whichever is higher at the time of harvest, and also accelerate market linkage with the farmers ${ }^{7}$. These private industries adopt buy-back system of marketing with Minimum Support Price (MSP). Thus, agroforestry practices also bring positive externalities through wood based industries for socio-economic and upliftment of farmers and economic benefits.

\section{Agroforestry systems in Tamil Nadu}

The prevailing agroforestry systems in TN mostly depend on economic returns, size of land holding, edaphic and climatic factors, and socio-economic dimensions. In general, block plantation, home gardens and bund planting are the common practices of agroforestry systems found in the state and the trees are catering to the needs of small timber, raw material for wood-based industries, food, fodder, fuel, soil conservation, etc. ${ }^{13}$. Different types of agroforestry systems such as agrisilviculture, agrihorticulture, silvipasture, hortisilviculture and boundary plantations are commonly practised in TN to fulfil the multifunctional needs of local people. Table 1 shows 


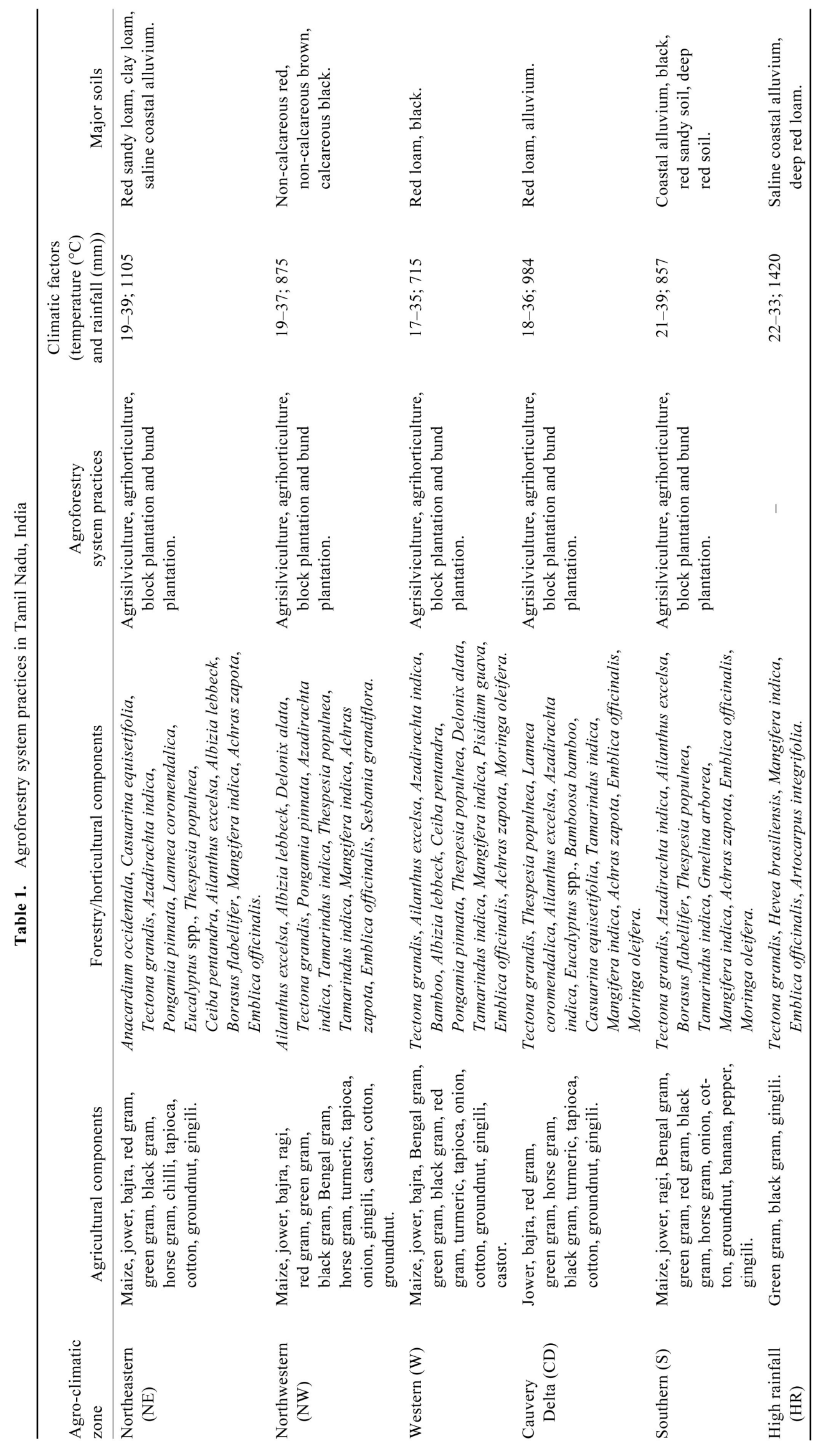


the different agroforestry systems in the state ${ }^{14}$. It reveals that horticulture species and industrial species like Casuarina, Eucalyptus, M. dubia, G. arborea, etc. exists in the form of agrisilviculture and hortisilviculture models, with annual crops of farmers' choice (based on local condition) mostly groundnut, black gram, turmeric, cotton, cowpea, etc. Timber species like teak, Gmelina, Albizia lebbeck, neem, etc. are highly preferable in farm bunds. The farmer's foremost preferences towards tree farming in farmlands are less competition and interaction with annual crops and without much reduction crop yield. Table 1 also reveals that farmers preference for horticultural species due to sustainable income from fruits and easy marketing. The marginal farmers (owners of up to 1 ha land) in the state widely practice traditional agroforestry due to lack of information about the advantages of industrial agroforestry and maintaining trees, especially in farm bunds to meet their daily needs. The selection of tree species depends on quick economic returns, less maintenance, meeting local needs, etc. Farmers who are practising traditional agroforestry systems do not receive much economic benefits other than meeting their day-today needs. Tree species like teak, neem, siris, gamhar, tamarind, silk cotton, aralu, Krishna siris, bamboo species, etc. are the commonly planted trees in farm bunds to meet multipurpose needs. These not only provide small timber but are also useful in traditional medicine, improving the microclimate, maintaining local biodiversity, harbouring birds and insect populations, etc.

\section{Farmers' acceptability of agroforestry}

Farmers in TN are practising agroforestry mainly to meet their day-to-day needs and for economic upliftment. The trees which are commonly grown under agroforestry in TN are Ailanthus excelsa, A. lebbeck, Delonix alata, Tectona grandis, Pongamia pinnata, Azadirachta indica, Tamarindus indica, Thespesia populnea, Tamarindus indica, Mangifera indica, Achras zapota, Emblica officinalis, Sesbania grandiflora, Syzygium cumini, Eucalyptus, Acacia leucophloea, Casuarina equisetifolia, Pithecellobium dulce, Ailantus exelsa, Albizia lebbeck, Bamboo, etc. Teak is an important timber species commonly found in farm bunds ${ }^{15}$. A . lebbeck is an important fast-growing tree mostly found in bunds in the state, having multiutility for making moulds, in the carving industry ${ }^{16}$, etc. Trees like neem and pungam are commonly planted mainly for medicinal and small timber purposes ${ }^{17,18}$. Horticultural species like mango, guava, banana, sapota, amla, papaya pomegranate, lemon, etc. are considered as an ideal option and are common in all the agroclimatic zones of $\mathrm{TN}^{19}$. The climatic and edaphic factors are favourable for fruit tree cultivation. Integration of horticultural species in farmlands helps in efficient utilization of natural resources and generates adequate income, provides employment and improves livelihood ${ }^{20}$. Agroforestry emerges as an effective tool for improvement of the rural economy due to low investment, high profitability and high income-generating practices ${ }^{21}$. Numerous agroforestry systems and combinations of annual crops are practised by the farming community in $\mathrm{TN}$ and many multipurpose trees are found compatible in various agroclimatic regions of the state. Trees like teak, Casuarina, sandal, Ailanthus, bamboo, amla, etc. are among the most suitable species, which can be grown under agroforestry with minimal crop yield reduction. Appropriate tree-crop arrangements can indicate which combination is better in terms of profitability and acts as a feasible option that provides livelihood security to the rural community with less supervision and inputs. These agroforestry combinations and systems help increase the economy of the farmers, provide food security and make them self-sufficient $(\text { Table } 2)^{22}$. The ecosystem services generated from agroforestry adoption will help ameliorate the micro-climate of farmlands to promote climate-resilient crops. These agroforestry programmes will be an effective tool for climate mitigation and adaption mechanism to counter climate change, and act as a sink for greenhouse gases ${ }^{23}$.

Table 3 indicates that nonavailability of agricultural labour (ranked first in four agroclimatic zones) and higher returns from tree components (ranked first in two agroclimatic zones) registered higher mean score and ranked among other reasons for adoption of agroforestry systems in different agroclimatic regions of TN. The other important reasons are less attention needed for tree species, less risk and fewer inputs compared to crops. Apart from the above reasons, climatic vagaries also play a vital role in the adoption of agroforestry systems among farmers throughout the state ${ }^{24}$. Non-availability of agricultural labour and their costs are the main factors for adoption of tree farming across the agroclimatic zones of $\mathrm{TN}^{25}$. The main determinants of adoption were age of farmers, household size, educational level, farm size, farming experience, income, access to credit and extension contacts. All these variables, except age of farmers, affected the adoption rate of agroforestry technologies positively ${ }^{26}$. The level of domestication and extent of adoption of agroforestry (Table 4) reveals that farmers are well aware of the type and quality of planting materials and they prefer quality planting materials especially high-yielding clones which will give more productivity than seed-source seedlings (Table 4). They are also knowledgeable about intercropping activities and size of pits for various tree components, including horticultural species. Also, they give equal importance for weeding and time of planting which is important for the establishment of tree components; it also reduces irrigation cost. Table 4 reveals that farmers are less attentive towards soil working, mulching and plant protection measures; they consider, these activities to be nonremunerative and as adding more cost in the maintenance of agroforestry 


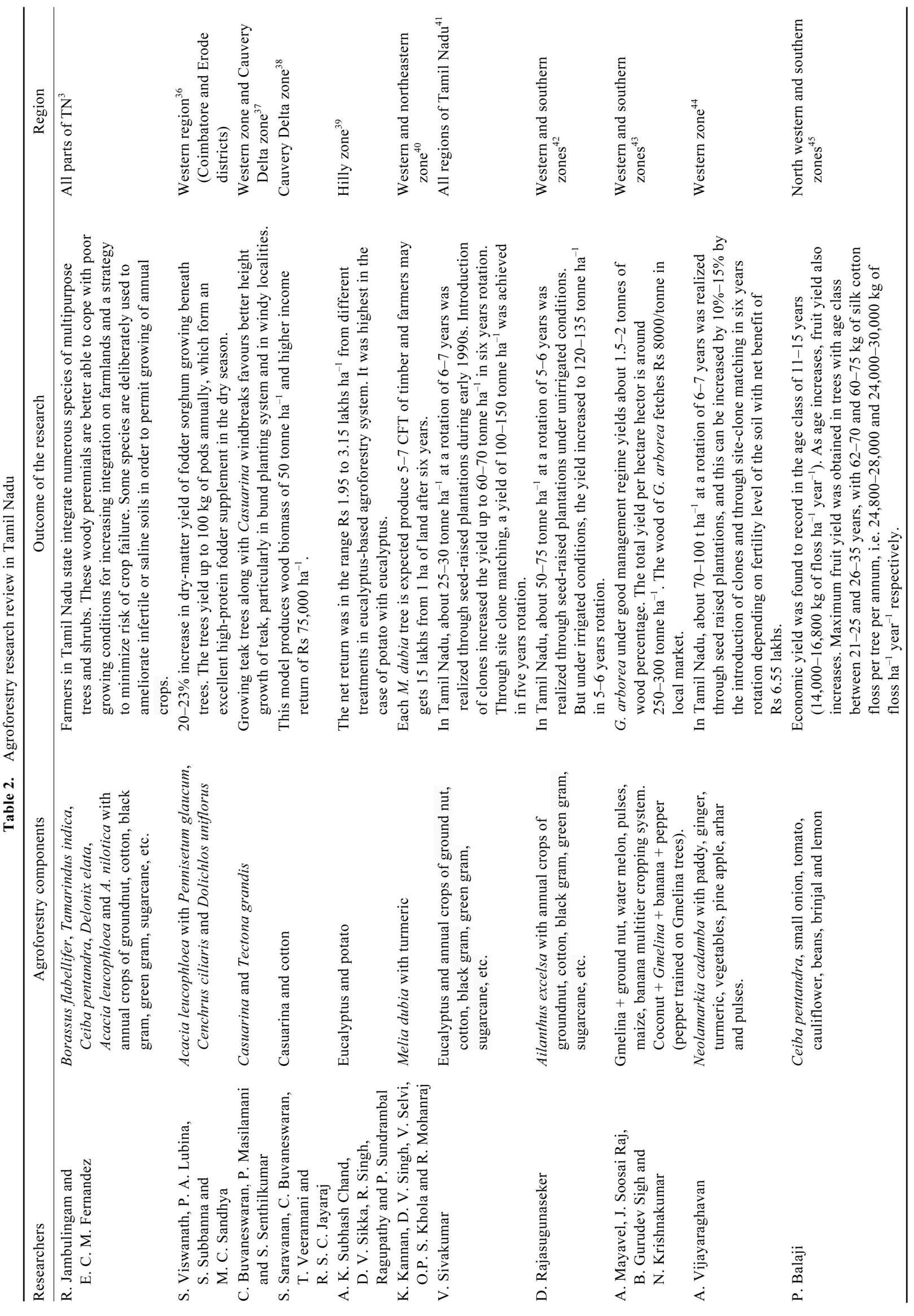



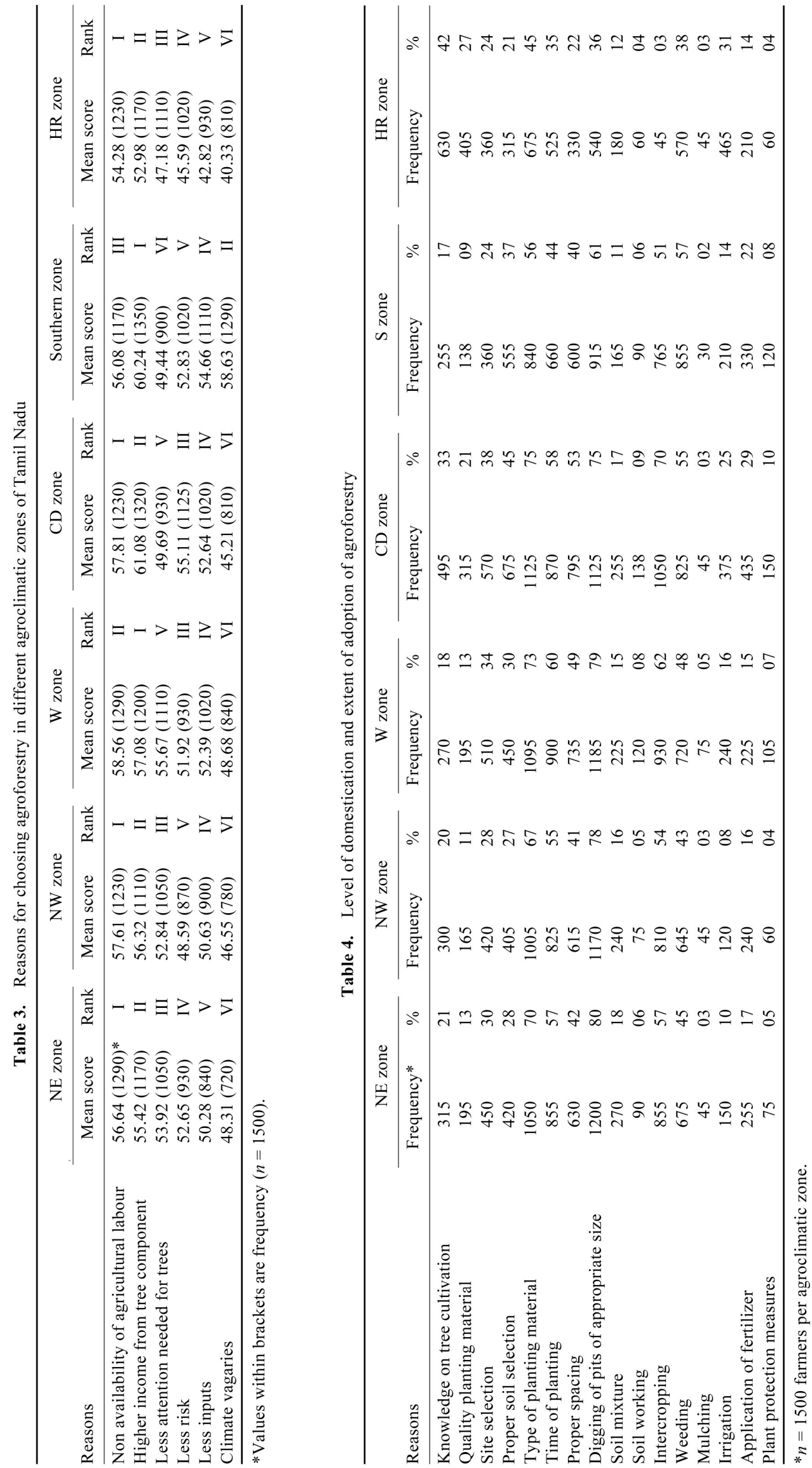
Table 5. Constraints faced by farmers in the adoption of agroforestry systems in Tamil Nadu

\begin{tabular}{|c|c|c|}
\hline Constraints & Frequency* & Percentage \\
\hline \multicolumn{3}{|l|}{ Labour } \\
\hline Nonavailability of agricultural labours & 7425 & 82.50 \\
\hline Higher wages to labourers & 7575 & 84.17 \\
\hline \multicolumn{3}{|l|}{ Inputs } \\
\hline Quality planting material & 7088 & 78.75 \\
\hline Cost of inputs like fertilizers & 4867 & 54.08 \\
\hline Cost of insecticides and pesticides & 2813 & 31.25 \\
\hline \multicolumn{3}{|l|}{ Technology } \\
\hline Nonavailability of silvicultural techniques & 7200 & 80.00 \\
\hline Poor extension strategy & 7875 & 87.50 \\
\hline \multicolumn{3}{|l|}{ Marketing } \\
\hline Nonavailability of marketing information & 8062 & 89.58 \\
\hline Monopoly in price fixation & 6563 & 72.92 \\
\hline Price fluctuation of agroforestry products & 7350 & 81.67 \\
\hline \multicolumn{3}{|l|}{ Loan/credit/insurance facilities } \\
\hline Nonavailability of tree loan & 8625 & 95.83 \\
\hline Nonavailability of tree insurance or lesser information & 8550 & 95.00 \\
\hline \multicolumn{3}{|l|}{ Others } \\
\hline Linkage with other tree growers associations & 6600 & 73.33 \\
\hline Linkage with Forest Departments, industries and research institutions & 7050 & 78.33 \\
\hline Sale through associations/federations & 7650 & 85.00 \\
\hline
\end{tabular}

systems. Table 5 presents the major constraints faced by the tree-growing farmers. These are divided into five major categories, viz. labour, inputs, technology, marketing, loan/credit and others. Table 5 shows that nonavailability of agriculture labour and their wages play a vital role in the adoption of tree farming. For tree farming-related activities, farmers can manage with a few labourers when it is necessary. Non-availability of quality planting materials or difficulty in accessing them also plays a major role and farmers depend mostly on local nurseries for planting stock, normally poor in quality, which will not give good returns in the future. Farmers also face constraints in the application of fertilizers and protection measures for tree components. Unlike in agriculture, for tree species, no or little information is available on establishment and management strategies (precision silvicultural techniques). This leads to poor management of the tree components resulting in yield and returns. Also, forestry extension strategies are not clear and reached among farmers compared to agriculture extension activities. Both aspects need to be strengthened for the welfare of tree-growers and greater adoption of tree farming. One of the major problems faced by the tree growers is the non-availability of loan (for establishment and maintenance period) and insurance (during crop failure due to biotic, abiotic factors and climate vagaries) facilities. Further, non-availability of marketing structure, linkage with other stakeholders, etc. are also major constraints faced by tree growers. We need to address the above problems for greater adoption of tree farming and higher economic returns to the farming community.

\section{Value chain and new marketing strategies for agroforestry products}

In the value chain, all the stakeholders involved in agroforestry systems are brought under a single platform which will benefit each other. In the value chain, the role of each stakeholder is specified and aimed to achieve $33 \%$ tree cover through agroforestry, maximum benefit to farmers, reduction in the import of wood and wood products, etc. Research institutions (ICFRE, TNAU, SFDs and wood-based industries) will provide quality planting materials (seedlings produced from seed orchards, seed stands and improved productive clonal materials) and latest cultivation techniques (precision silvicultural techniques for higher productivity) to the farmers with assurance from the wood-based industries MSP for agroforestry products and support from financial institutions (bank loans and insurance for tree components), etc. It is important to develop a well-structured market for agroforestry products mainly for trouble-free sale and quick economic returns to the tree-growers. In $\mathrm{TN}$, the value chain in industrial agroforestry plays a major role in marketing of agroforestry products. In this value chain, wood-based industries are coming forward to take the agroforestry products with assured marketing and MSP. Also, they have entered into MoUs with the tree-growers, which will encourage the latter towards adoption and expansion of agroforestry in a larger area. These industrial approaches influence/motivate the farmers to adopt agroforestry practices on a large scale in TN. The PPP (private-public-partnership) in agroforestry is also taking 
momentum in the state, with a view that the harvested agroforestry products from farm must be delivered to the industry at the market rate with buy-back guarantee. The agroforestry consortium also identifies appropriate farmlands for plantations with various industrial tree species, and improvement of the interface between farmers and industries for better market linkage (Figures 1 and 2) ${ }^{27}$.

\section{Role of research, education and extension in the promotion of agroforestry}

$\mathrm{TN}$ has the potential to develop an expansion of ecologically and economically viable and socially acceptable agroforestry systems for the improvement of farmers' livelihood status. Various research institutions have developed successful agroforestry systems for higher economic returns that are being adopted in different regions of TN, viz. Melia, Eucalyptus, Casuarina, G. arborea, A. excelsa based agrisilvi model; mango, guava, sapota, lemon, papaya, amla based silvihorti models; A. leucophloea with C. ciliaris-based silvipasture model and bund planting with important valuable trees like teak, sissoo, A. lebbeck, neem, tamarind, jamun, etc. $\mathrm{TN}$ has important research institutions like the Institute of Forest Genetics and Tree Breeding (IFGTB), Forest College and Research Institute (TNAU), SFD and woodbased industries are currently involved in long-term breeding programmes in indigenous and exotic species aimed to bring out high productivity varieties and clonal materials which are highly beneficial to tree-growers ${ }^{28}$. Also, these research institutions are involved in agroforestry research for developing economically viable models which can give more income to farmers. Like in agriculture, forestry, especially agroforestry also requires strong extension support for expansion to more farmers. For this, forestry extension should be strengthened through

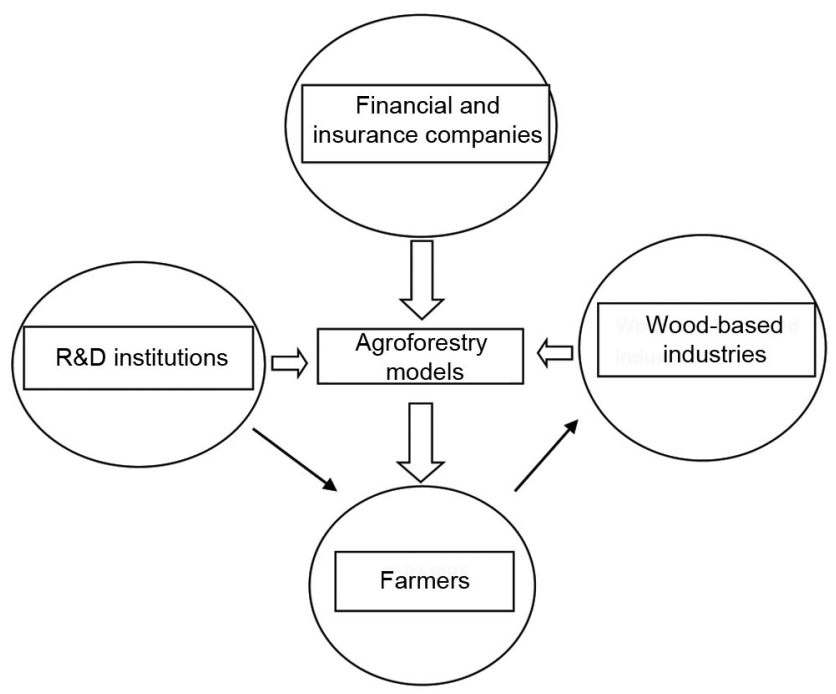

Figure 1. Value chain in the agroforestry system. the establishment of Van Vigyan Kendras (VVKs) and more subject-matter specialists should be posted in VVKs to achieve the targets in agroforestry field. At present, IFGTB has set up VVKs in TN to promote agroforestry systems among farmers in a successful manner. The SFD has also established Forestry Extension Centres in each district to promote agroforestry among farmers through establishment of demonstration plots, supplying quality planting materials to them at low cost. Research institutions and SFD are helping to educate the stakeholders and sustainably expand the horizons of agroforestry in the state. Poverty alleviation is not possible without modernization of the agriculture and forestry sector. Poverty alleviation, sustainable forest management, and sustainable agriculture and livestock management are interlinked ${ }^{29}$. Hence, growing trees on farmlands results in economic, social and environmental benefits for the land users $^{30}$.

\section{Strategies and challenges in the promotion of agroforestry in TN}

Agroforestry is playing a vital role in maintaining natural resources and increasing overall productivity with minimizing risk against the vagaries of weather. A variety of tree-crop combinations are followed by the farmers according to their needs and variability in the agro-climatic zones of the state. Multipurpose tree species are the choice to integrate with annual crops/vegetables/ medicinal plants or with grasses. Although agroforestry is practised in India since ancient times, it has not gained importance due to dependency on multi-institutions and multi-disciplinary approach ${ }^{31}$. The NAP-2014 has indicated the way forward to promoting agroforestry among various stakeholders. There should be proper coordination between various stakeholders of agroforestry like researchers, extension workers, industries, farmers etc. India is a land of variability in terms of climate, soil, etc. Hence location-specific and economically sound agroforestry systems need to be developed. Agroforestry land use has great potential in providing ecosystem services; hence, these services should be quantified as accurately as possible.

The sustainable land-use system approach is required at this juncture to overcome uncertainty of the monsoon and frequent natural calamities, and to maintain food security $^{32}$. Usually, lack of scientific knowledge, institutional approach and negative attributes of tree components (viz. long rotation, shade effect, opportunity cost, etc.) discourage farmers from adopting tree farming. However, recent developments in the production, processing and consumption sectors have generated interest among farmers to adopt agroforestry systems holistically for higher economic returns. The present probable area under agroforestry in India is estimated to 


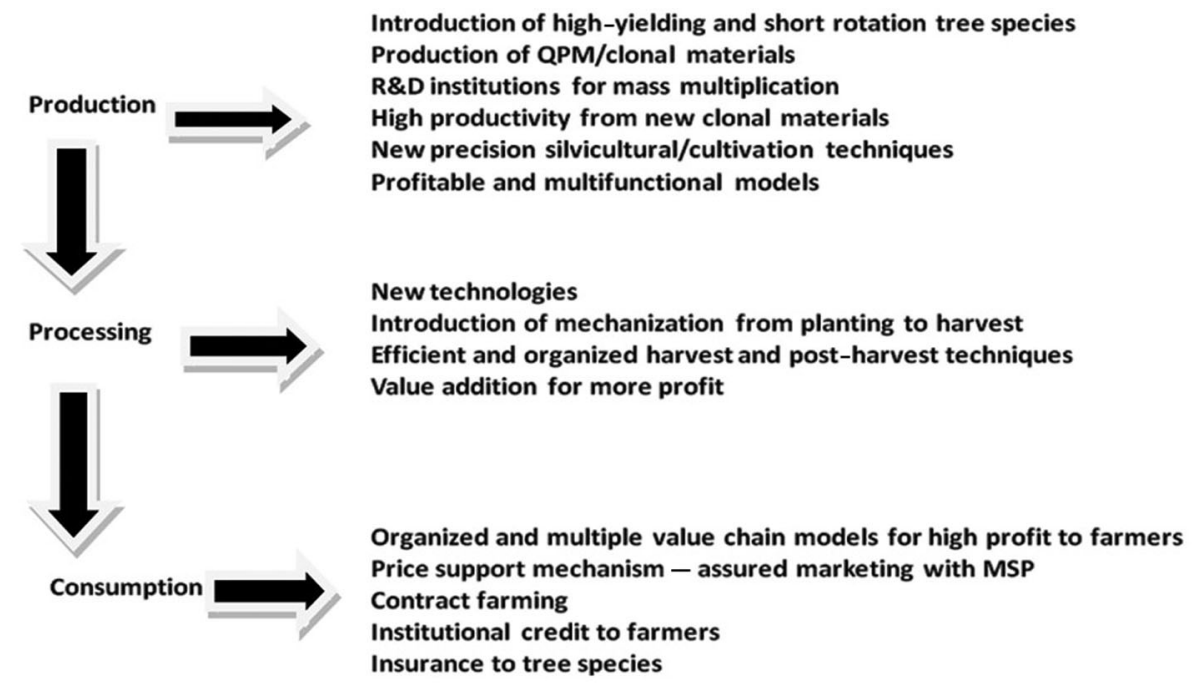

Figure 2. Strategies for agroforestry promotion ${ }^{27}$.

be $25.32 \mathrm{~m}$ ha, or $8.2 \%$ of the total geographical area of the country ${ }^{33}$. However, Forest Survey of India, 2013 estimated the area under agroforestry to be $11.54 \mathrm{~m} \mathrm{ha}$, which is $3.39 \%$ of the geographical area of the country; and in TN it is only $4671 \mathrm{sq} . \mathrm{km}$, which is $3.59 \%$ of the total geographical area of the state. Despite encouragement for growing trees on farmlands, the farmers of TN have to deal with many constraints and limitations related to agroforestry. The difficulty in felling, harvesting, transit pass and marketing (rights on cutting and selling of wood), and insecure regulation discourage them to cultivate trees ${ }^{34}$.

\section{Conclusion}

We are in the era to feed various stakeholders such us people, wood based industries, etc. Practising of agriculture alone will not fulfil the small and marginal farmers' needs due to climatic vagaries, increasing pressure on practising agriculture, declining size of land holdings and conversion of agricultural land to non agricultural purposes. To overcome these problems, agroforestry is a solution that will improve the livelihood of the farming community through cluster approach and value chain models by bringing all the stakeholders under one common platform. Incorporation of trees/livestock within the farmlands will generate adequate income and generate rural employment ${ }^{35}$ (approximately 145 man day's ha ${ }^{-1}$ ). The central and state government research institutions, SFD and wood-based industries are promoting agroforestry and farm forestry at a large scale in TN with precision silvicultural techniques and assured price mechanism. These initiatives will not only fulfil the domestic and economic needs of the farmers, but also provide several environmental benefits. Moreover, pro- moting agroforestry by the merging of various ongoing central and state government schemes (as mentioned in the NAP 2014), will give a boost to the farmers and bring more area under tree cover (agroforestry). Finally, agroforestry practices are needed to maintain the natural (forest) resources and agrarian identity at the national level.

1. NAC, Conservation in a changing climate, USDA National Agroforestry Centre.

2. Jose, S., Agroforestry for ecosystem services and environmental benefits: an overview. Agrofor. Syst., 2009, 76(1), 1-10; doi: 10.1007/s10457-009-9229-7.

3. Jambulingam, R. and Fernandes, E. C. M., Multipurpose trees and shrubs on farmlands in Tamil Nadu State (India). Agrofor. Syst., 1986, 4, 17-32.

4. FSI, India State of Forest Report, Forest Survey of India, Dehra Dun, 2019.

5. MoHA, Census, Ministry of Home Affairs, Government of India (GoI), 2011.

6. https://www.tn.gov.in/department/2

7. http://bilttreetech.com/about-history.asp

8. National Forest Policy, Ministry of Environment and Forests, GoI, 1988.

9. National Agroforestry Policy, Ministry of Agriculture, GoI, 2014.

10. https://www.forests.tn.gov.in/pages/view/tap

11. https://www.forests.tn.gov.in/pages/view/tcpl

12. http://agritech.tnau.ac.in/forestry/pdf/schemes

13. Saravanan, S., Documentation of agroforestry models in Tamil Nadu. Agro-forestry Project completion report, Department of Forestry, Land Use and Climate Change, Institute of Forest Genetics and Tree Breeding, Coimbatore, India, 2010.

14. Saravanan, S., Documentation of agroforestry systems and wood flow to wood based industries in Tamil Nadu. Project completion report, Department of Forestry, Land Use and Climate Change, Institute of Forest Genetics and Tree Breeding, Coimbatore, 2014.

15. http://www.teaknet.org/images/12-\%20Teak\%20Farming.pdf

16. Kannan, C. S., Warrier, Manual of Economically Important Forestry Species of South India, Institute of Forest Genetics and Tree Breeding, Coimbatore, 2010.

17. http://agritech.tnau.ac.in/bio-fuels/Biofuel_Neem.html 
18. Prabakaran, P., Kumaran, K., Baburaj, L. K., Balaji, S., Mageshram, S., Balakumar, C. and Radhakrishnan, R., Variability studies on seed parameters, oil and azadirachtin content of neem (Azadirachta indica A. Juss.) in Tamil Nadu and Karnataka. Int. J. Curr. Microbiol. Appl. Sci., 2019, 8(5), 339-346.

19. http://agritech.tnau.ac.in/pdf/2013/cpg horti_2013.pdf

20. Nanjundiah, S. K., Impact of improved horticulture farming technology on farmers' livelihoods in India, 2015, 10.13140/ RG.2.1.2657.8405.

21. Current, D., Lutz, E. and Scherr, S. J., The costs and benefits of agroforestry to farmers. World Bank Res. Observ., 1995, 10(2), 151-180.

22. Bijalwan, A., Verma, P., Manmohan, D. J. R., Patil, A. K., Thakur, T. K. and Sharma, C. M., Trends and insights of agroforestry practices in Madhya Pradesh, India. Curr. Sci., 2019, 117(4), 597605

23. Dobriyal, M. J., Dashora, L. K., Maloo, S. R. and Sarolia, D., Improvement in livelihoods and benefits of small and marginal farmers through agroforestry interventions with carbon finance. In Proceedings of National Seminar on Agroforestry: An Evergreen Agriculture for Food Security and Environmental Resilience, Navsari Agricultural University, Navsari, 2-4 February 2012, pp. 201-211.

24. Saravanan, S., Cultivation of Melia dubia Cav. - a fast growing native tree species and constraints faced by the farmers in western region of Tamil Nadu. Indian J. Agrofor., 2017, 19(2), 56-60.

25. Saravanan, S., Constraints faced by farmers in adoption of Gmelina arborea - a case study in Tamil Nadu. Indian J. Hill Farm, 2012, 25(1), 13-16.

26. Sangeetha, R., Shanmugam, T. R. and Nandhini, S., Factors affecting adoption rate of agroforestry technologies in Tamil Nadu. Agric. Econ. Res. Rev., 2016, 29, 307; 10.5958/09740279.2016.00058.6.

27. Parthiban, K., Fernandaz, C. and Krishna Kumar, Consortium of Industrial Agroforestry: an institutional mechanism for sustaining agroforestry in India. Curr. Sci., 2019, 117, 30-36; 10.18520/ cs/v117/i1/30-36.

28. Chavan, S. B., Keerthika, A., Dhyani, S. K., Handa, A. K., Newaj, R. and Rajarajan, K., National Agroforestry Policy in India: a low hanging fruit. Curr. Sci., 2015, 108(10), 1826.

29. Pandey, D. N., Multifunctional agroforestry system in India. Curr. Sci., 2007, 92(4), 455-463.

30. Lasco, R. D., Delfino, R. J. P., Catacutan, D. C., Simelton, E. S. and Wilson, D. M., Climate risk adaptation by smallholder farmers: the roles of trees and agroforestry. Curr. Opin. Environ. Sustain., 2014, 6, 83-88.

31. Dhyani, S. K. and Handa, A. K., Agroforestry in India: current scenario. Indian Farm., 2014, 63(11), 6-8.

32. Dhyani, S. K., National Agroforestry Policy 2014 and the need for area estimation under agroforestry. Curr. Sci., 2014, 107(1), 9-10.
33. Chambers, R. and Leach, M., Trees as savings and security for the rural poor. World Dev., 1989, 17(3), 329-342.

34. Pandey, C. B., Pandya, K. S., Pandey, D. and Sharma, R. B., Growth and productivity of rice (Oryza sativa) as affected by Acacia nilotica in a traditional agroforestry system. Trop. Ecol., 1999 40(1), 109-117.

35. Shukla, S. and Pandey, V. V., Agroforestry systems as a tool in sustainable rural development, food scarcity and income generation. Indian For., 2018, 144(5), 435-441.

36. Viswanath, S., Lubina, P. A., Subbanna, S. and Sandhya, M. C., Traditional agroforestry systems and practices: a review. $A d v$. Agricul. Res. Technol. J., 2018, 2(1), 18-29.

37. Buvaneswaran, C., Masilamani, P. and Senthilkumar, S., Windbreaks of Casuarina for tailoring growth and branching pattern of teak trees in bund planting system. Int. J. Appl. Agricul. Res., 2016, 15(1), 33-42.

38. Saravanan, S., Buvaneswaran, C., Veeramani, T. and Jayaraj, R. S C., Casuarina equisetifolia based agroforestry system in Cauvery Delta zone of Tamil Nadu for higher economic returns. In Casuarinas in India. Proceedings of Second National seminar on Casuarinas (eds Jayaraj, R. S. C. et al.), 2012.

39. Subhash, C., Sikka, A., Singh, D., Ragupathy, R. and Sundrambal, P., Comparison of acacia and eucalyptus agroforestry system for hills: Tamil Nadu, India. Int. J. Manage. Soc. Sci., 2015, 3(2), 990-1000.

40. Kannan, K., Singh, D. V., Selvi, V., Khola, O. P. S. and Mohanraj, R., Malai Vembu (Melia dubia) - for farm and agro forestry. Central Soil and Water Conservation Research and Training Institute, Research Centre (Indian Council of Agricultural Research), Udhagamandalam, 2013.

41. Sivakumar, V., Cultivation techniques for eucalyptus. In Transfer of Tree Cultivation Techniques, Institute of Forest Genetics and Tree Breeding, Coimbatore, 2014

42. Rajasugunaseker, D., Cultivation techniques for Ailanthus excelsa. In Transfer of Tree Cultivation Techniques, Institute of Forest Genetics and Tree Breeding, Coimbatore, 2014.

43. Mayavel, A., Soosai Raj, J., Gurudev Sigh, B. and Krishnakumar, N., Cultivation techniques for Gmelina arborea. In Transfer of Tree Cultivation Techniques, Institute of Forest Genetics and Tree Breeding, Coimbatore, 2014.

44. Vijayaraghavan, A., Cultivation techniques for Neolamarkia cadamba. In Transfer of Tree Cultivation Techniques, Institute of Forest Genetics and Tree Breeding, Coimbatore, 2014.

45. Balaji, P., Fruit yield and economic analysis of selected tree species (STS) under agro- forestry system in Tamil Nadu. Research final report, 2017, Industrial Wood research division, Tiruchirappalli, 2017.

Received 2 June 2020; revised accepted 24 November 2020

doi: $10.18520 / \mathrm{cs} / \mathrm{v} 120 / \mathrm{i} 4 / 644-653$ 